\title{
Cyclic Strain Upregulates Nitric Oxide Synthase in Cultured Bovine Aortic Endothelial Cells
}

Mark A. Awolesi, William C. Sessa, ${ }^{\star}$ and Bauer E. Sumpio

Department of Surgery and Pharmacology and *Molecular Cardiobiology, Yale University School of Medicine, New Haven, Connecticut 06510

\begin{abstract}
In vivo, endothelial cells (EC) are subjected to hemodynamic forces which may influence the production of nitric oxide. This study was designed to examine the effect of cyclic strain on the expression of endothelial nitric oxide synthase (eNOS) in cultured bovine aortic EC. EC were grown on flexible membranes which were subjected to deformation at 60 cycles/min with -5 or $-20 \mathrm{kPa}$ of vacuum. This results in an average strain of 6 and $10 \%$, respectively, which is transmitted to the attached cells. Northern blot analysis of total cytosolic RNA demonstrated an increase in eNOS gene expression with both strain regimens but the increase with $10 \%$ average strain was greater than that at $6 \%$. Nuclear runoff transcription assays confirmed the induction of eNOS transcripts. Western blot analysis showed an increase in eNOS level after $24 \mathrm{~h}$ of cyclic $10 \%$ average strain compared with controls or $6 \%$ average strain. Immunohistochemical staining of EC for eNOS was increased in the high strain periphery (7-24\% strain) of membranes deformed with $-20 \mathrm{kPa}$ vacuum. These results demonstrate that cyclic strain upregulates the expression of eNOS transcripts and protein levels in bovine aortic EC thus emphasizing the importance of hemodynamic forces in the regulation of eNOS in vivo. ( $J$. Clin. Invest. 1995. 96:1449-1454.) Key words: endothelium • hemodynamic - gene expression • vascular • nitric oxide
\end{abstract}

\section{Introduction}

Endothelium-derived nitric oxide (NO) ${ }^{1}$ is an endogenous vasorelaxant with antiplatelet (1) and antileukocyte properties (2). In endothelial cells (EC), NO is synthesized by a membrane-associated, calcium/calmodulin-dependent enzyme, nitric oxide synthase (eNOS), that metabolizes one of the equivalent guanidino nitrogens of L-arginine to NO and the by-product, Lcitrulline $(3-5)$. Tetrahydrobiopterin, flavin mononucleotide,

Address correspondence to Bauer E. Sumpio, MD, PhD, Dept. of Surgery (Vascular), Yale University School of Medicine, 333 Cedar Street, New Haven, CT 06510. Phone: 203-785-2561; FAX: 203-785-7609. Received for publication 15 August 1994 and accepted in revised form 16 May 1995.

1. Abbreviations used in this paper: CRE, cAMP responsive element; EC, endothelial cells; eNOS, endothelial nitric oxide synthase; GAPDH, glyceraldehyde-3-phosphate dehydrogenase; NO, nitric oxide.

J. Clin. Invest.

(C) The American Society for Clinical Investigation, Inc. 0021-9738/95/09/1449/06\$2.00

Volume 96, September 1995, 1449-1454 and flavin adenine dinucleotide are cofactors, while reduced nicotinamide adenine dinucleotide phosphate (NADPH) (6) and molecular oxygen (7) are necessary cosubstrates for optimal NOS activity. Bovine and human eNOS cDNAs have been cloned $(8,9)$ and recently the structure of the human gene was described and mapped to chromosome 7 (10). However, very little is known about the regulation of this important enzyme.

In vivo, local autocoids ( such as bradykinin, ATP, or histamine) and the forces of the circulation acting on the endothelium appear to regulate the production of NO. Hormonal stimulation or acute changes in flow can cause the immediate release of NO presumably through mobilization of calcium, which is necessary for eNOS activation $(11,12)$. Chronic increases in blood flow result in a more prolonged release of NO, suggesting induction of eNOS gene or the cofactors necessary for the production of NO by EC. Chronic increases in blood flow (via arterio-venous fistulas) enhance endothelium-dependent relaxations in vessels exposed to the higher flow rates (13). In addition, chronic exercise in dogs enhances endothelium-dependent epicardial dilation in vivo and increases the release of nitrogen oxides from large coronary arteries in vitro. The enhanced NO production was associated with an increase in eNOS gene expression in aortic EC extracts (14), suggesting that exercise-induced elevations of cardiac output and aortic flow rates can upregulate the eNOS gene.

The contribution and importance of specific hemodynamic forces, such as shear stress, cyclic strain, or cyclic distention of the arterial wall and blood pressure, to the regulation of eNOS have not been fully defined. Recently it was shown that shear stress upregulates steady state eNOS mRNA levels in cultured bovine aortic EC (15). Because EC, in vivo, are exposed to cyclic distention, the aim of our study was to determine the effect of cyclic strain on eNOS gene expression and protein in cultured bovine aortic EC. Previous studies in our laboratory examining the effects of cyclic $10 \%$ average strain on bovine aortic EC have demonstrated activation of intracellular second messengers, including translocation of protein kinase $\mathrm{C}$, phosphatidyl-inositol turnover, activation of the protein kinase A/ adenylate cyclase pathway, and increases in intracellular calcium (16-19). In addition, exposure of EC to this cyclic strain regimen enhances proliferation and modifies the production of vasoactive substances such as prostacyclin, endothelin, and tissue plasminogen activator (20-24). Therefore, we used the above strain protocol to examine the effects on eNOS expression.

\section{Methods}

Cell culture. Bovine aortic EC were obtained by gently scraping the intimal surface of bovine thoracic aorta and maintained in DME F-12 1:1 mixture (with $50 \mathrm{mM}$ Hepes buffer, $\mathrm{pH} 7.2,10 \mathrm{mM}$ glutamine, and $\mathrm{NaHCO}_{3}$ ), supplemented with $10 \%$ heat-inactivated calf serum, $5 \mu \mathrm{g} /$ $\mathrm{ml}$ deoxycytidine/thymidine, antibiotics (penicillin $100 \mathrm{U} / \mathrm{ml}$, strepto- 
mycin $100 \mu \mathrm{g} / \mathrm{ml})$, and amphotericin B $(250 \mathrm{ng} / \mathrm{ml})$. Bovine aortic EC were identified by their typical morphologic and chemical characteristics including growth of closely opposed polygonal confluent monolayers, maintenance of density-dependent inhibition after serial passage, positive indirect immunofluorescence staining for Factor VIII antigen, and the uptake of di-I-acetylated LDL.

Experimental protocol. The strain unit (Flexercell; Flexcell International Corp., McKeesport, PA) consists of a vacuum manifold with recessed ports and has been described in detail previously (25). Bovine aortic EC were cultured on plates with bottoms made of flexible silastic covered with a hydrophilic surface (Flex I; Flexcell International Corp.). The plates are centered over ports on the vacuum manifold. A vacuum line is connected to regulator solenoid valves which are in turn controlled by a computer with a timer program. Thus, the design of the strain unit allows for changes in amplitude, frequency, and duration of the applied strain for each given experiment.

For these experiments, bovine aortic EC were seeded onto Flex I stretch plates and grown to confluence. The membranes were subjected to deformation with -5 and $-20 \mathrm{kPa}$ of vacuum at a frequency of 60 cycles $/ \mathrm{min}(0.5 \mathrm{~s}$ of deformation alternating with $0.5 \mathrm{~s}$ of relaxation) for up to $24 \mathrm{~h}$. $-20 \mathrm{kPa}$ of vacuum produces a deformation pattern ranging from $0 \%$ at the center of the membrane to $24 \%$ at the periphery (average strain $=10 \%$ ), $-5 \mathrm{kPa}$ results in a deformation ranging from $0 \%$ in the center to a maximum of $10 \%$ in the periphery (average strain $=6 \%$ ) (26). For the sake of simplicity, the two experimental groups are referred to as the 10 and $6 \%$ average strain groups, respectively.

The highest strain is found in a region $9.5 \mathrm{~mm}$ from the center of a 25-mm diameter well. Thus, in some experiments, we took advantage of the heterogenous strain gradient by using a fence to selectively seed cells either in the central low strain region of the membrane or in the peripheral high strain region $(20,24)$. The fence was removed after 24 $\mathrm{h}$ and the selectively seeded plates were then subjected to deformation by $-20 \mathrm{kPa}$ vacuum at $60 \mathrm{cycles} / \mathrm{min}$; cells seeded in the periphery experienced $7-24 \%$ strain, whereas the cells seeded at the center experienced $<7 \%$ strain with the majority of cells exposed to minimal strain.

Northern blot analysis for eNOS. Total cytosolic RNA from stationary (control) EC and from EC that had been stretched for up to $24 \mathrm{~h}$ was isolated by the guanidinium isothiocyanate method with phenol extraction as previously described (27). RNA (10-15 $\mu \mathrm{g})$ was electrophoresed through a $1 \%$ agarose $/ 1.1 \%$ formaldehyde gel, transferred to a nylon membrane (Zeta Bind; American Bioanalytical, Natick, MA), and immobilized by ultraviolet irradiation. Hybridization was then performed with a random primed, $\left[\alpha-{ }^{32} \mathrm{P}\right] \mathrm{dCTP}-$ labeled, full-length cDNA probe coding for bovine eNOS (detects 4.4-kb mRNA) or human glyceraldehyde-3-phosphate dehydrogenase (GAPDH) (detects 1.2-kb mRNA) as previously described (8). Autoradiography was carried out for 1-3 d utilizing Kodak X-Omat AR-5 and Kodak XRP1 film and intensifying screens. Optical densities of hybridization signals on $\mathrm{x}$-ray films were measured by densitometry (Visage 2000 Gel Analyzer; Bio Image Products, Ann Arbor, MI) for quantitation of steady state mRNA levels.

Nuclear runoff transcription assays. Nuclear transcription assays were performed with slight modifications of the procedure described by Greenberg and Ziff (28). To isolate nuclei, stationary EC and EC that have been exposed to $10 \%$ average strain for $4 \mathrm{~h}$ were lysed in buffer containing $10 \mathrm{mM}$ Tris- $\mathrm{HCl}, \mathrm{pH} 7.4,10 \mathrm{mM} \mathrm{NaCl}, 3 \mathrm{mM} \mathrm{MgCl}$, and $0.5 \%$ Nonidet $\mathrm{P}-40$ and the nuclei were recovered by centrifugation at $500 \mathrm{~g}$ for $5 \mathrm{~min}$ at $4^{\circ} \mathrm{C}$. The nuclei were then resuspended at $26^{\circ} \mathrm{C}$ for $30 \mathrm{~min}$ in runoff buffer ( $35 \%$ glycerol, $10 \mathrm{mM}$ Tris- $\mathrm{HCl}, \mathrm{pH} 8.0,5$ $\mathrm{mM} \mathrm{MgCl}, 80 \mathrm{mM} \mathrm{KCl}, 0.1 \mathrm{mM}$ EDTA, $0.5 \mathrm{mM}$ DTT, $0.8 \mathrm{U}$ RNasin, $4 \mathrm{mM}$ dATP, $4 \mathrm{mM}$ dGTP, and $4 \mathrm{mM} \mathrm{dCTP}$ ) and $200 \mu \mathrm{Ci}\left[\alpha-{ }^{32} \mathrm{P}\right] \mathrm{UTP}$ $(3,000 \mathrm{Ci} / \mathrm{mmol}$; Amersham Corp., Arlington Heights, IL). The nuclei were next digested with $10 \mu \mathrm{g}$ DNase 1 (RNase free) at $26^{\circ} \mathrm{C}$ for 5 min followed by incubation with $10-20 \mathrm{mg}$ of proteinase $\mathrm{K}$ in buffer containing 5\% SDS, $50 \mathrm{mM}$ EDTA, and $100 \mathrm{mM}$ Tris- $\mathrm{HCl}, \mathrm{pH}$ 8.0, for $30 \mathrm{~min}$ at $37^{\circ} \mathrm{C}$. Nascent elongated transcripts of radiolabeled RNA molecules were extracted by the guanidinium isothiocyanate method
(27), precipitated with isopropanol, and dissolved in buffer containing $50 \mathrm{mM}$ Tris- $\mathrm{HCl}, \mathrm{pH} 8.0,150 \mathrm{mM} \mathrm{NaCl}$, and $1 \mathrm{mM}$ EDTA.

The level of incorporation of radioisotope was quantified in a beta counter and a volume containing equal counts (for controls and for cells exposed to cyclic strain) was then hybridized over $24 \mathrm{~h}$ at $65^{\circ} \mathrm{C}$ with membranes onto which linearized and alkaline-denatured eNOS and GAPDH probes had been immobilized by a slot blot apparatus and ultraviolet radiation.

The membranes are then washed twice with $2 \times \mathrm{SSC}$ at room temperature for $15 \mathrm{~min}$ followed by $1 \times \mathrm{SSC}$ at $65^{\circ} \mathrm{C}$ for $15 \mathrm{~min}$. Autoradiography was carried out for 1-3 d using Kodak X-Omat AR-5 and Kodak XRP1 film and intensifying screens.

Western blotting for eNOS. Bovine aortic EC on Flex I plates exposed to 6 and $10 \%$ average strain at 60 cycles $/ \mathrm{min}$ for $24 \mathrm{~h}$ were harvested by scraping and then centrifuged $(1,000 \mathrm{~g})$ for $5 \mathrm{~min}$ at $4^{\circ} \mathrm{C}$. The pellet was resuspended and homogenized with a glass-glass Dounce homogenizer in $0.5 \mathrm{ml}$ of homogenization buffer $(50 \mathrm{mM}$ Tris- $\mathrm{HCl}, \mathrm{pH}$ 7.4, $0.1 \mathrm{mM}$ EGTA, $0.1 \mathrm{mM}$ EDTA, $1 \mathrm{mM}$ DTT, $0.01 \mathrm{mg} / \mathrm{ml}$ leupeptin, $1.0 \mathrm{ng} / \mathrm{ml}$ chymostatin, and $1 \mathrm{mM}$ PMSF, $\mathrm{pH} 7.5$ ). The samples were centrifuged for $45 \mathrm{~min}$ at $10,000 \mathrm{~g}$ and the pellets were resuspended in Laemmeli buffer at a ratio of $1: 1$ and boiled for $4 \mathrm{~min}$. Protein concentration was determined by the Bradford assay (Bio Rad Laboratories, Hercules, CA) and equal amounts of protein were loaded into a $7.5 \%$ SDS-polyacrylamide minigel and electrophoresed at a constant current of $20 \mathrm{~mA}$ per gel for 1-2 h. One gel was stained with Coomassie blue to confirm equal protein loading while the other gel was transblotted. The blots were incubated overnight in Tris-buffered saline (TBS) containing 5\% milk to block nonspecific binding of the antibody. The blots were then washed in TBS and incubated for $2 \mathrm{~h}$ with an affinity-purified monoclonal bovine eNOS antibody $\mathrm{H} 32, \operatorname{IgG}_{2 \mathrm{a}}$ isotype $(1: 1,000)(6)$ at room temperature. Blots were washed (TBS $\times 2$ ) and then incubated for $1 \mathrm{~h}$ with a sheep anti-mouse secondary antibody conjugated to horseradish peroxidase. eNOS immunoreactivity was detected by the enhanced chemiluminescence (Amersham Corp.) method followed by autoradiography using Kodak X-Omat AR-5.

Immunohistochemical staining for eNOS. Bovine aortic EC exposed to 6 and $10 \%$ average strain for $24 \mathrm{~h}$ at 60 cycles/min were stained with the bovine eNOS antibody as previously described (6). In brief, cells were first fixed in $1 \%$ paraformaldehyde $/ 0.1 \mathrm{M}$ borate buffer, blocked with normal horse serum 1:200, and then the bovine eNOS antibody (isotype $\operatorname{IgG}_{2 \mathrm{a}}, 1: 2,000$ ) was added for $1 \mathrm{~h}$. Binding of antibody was detected by the avidin-biotin, horseradish peroxidase method with $0.05 \%$ 3-3' diaminobenzidine tetrachloride in $0.05 \mathrm{M}$ Tris- $\mathrm{HCl}$, $\mathrm{pH} 7.4$, as the substrate. Specificity of the staining was assessed by incubating the cells to nonspecific mouse $\operatorname{IgG}_{2 \mathrm{a}}$ or to the biotinylated secondary antibody only.

Statistical analysis. Data are presented as means \pm SD. Student's paired or unpaired $t$ tests were used to determine the significance of differences between means and $P<0.05$ was considered significant.

\section{Results}

Fig. $1 A$ shows a typical Northern blot of RNAs extracted from EC exposed to $10 \%$ average strain at 60 cycles $/ \mathrm{min}$. Cyclic strain ( $15 \mathrm{~min}$ to $24 \mathrm{~h}$ ) increased eNOS steady state mRNA levels compared with stationary controls. Densitometric analysis of eNOS gene expression compared with GAPDH expression showed a $3.1 \pm 0.2$-fold increase in bovine aortic EC exposed to strain compared with control (stationary) cells ( $n=$ 4). To determine whether this increase in eNOS gene expression was dependent on the amplitude of strain, EC were exposed to $6 \%$ average strain at 60 cycles $/ \mathrm{min}$ for various times. Fig. $1 B$ demonstrates that this level of strain also increased the expression of the eNOS gene but to a lesser extent than that seen with EC subjected to $10 \%$ average strain. The increase in gene expression was not evident until the cells were exposed to strain 
A

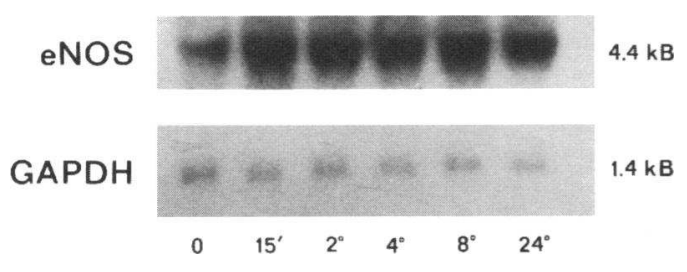

B

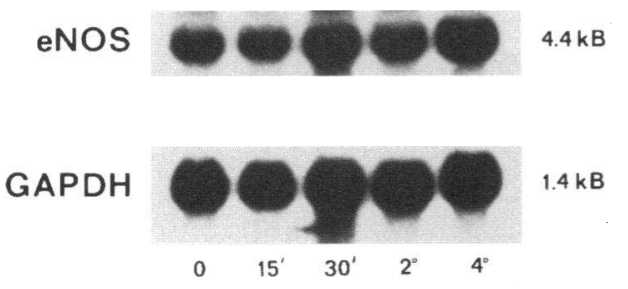

C

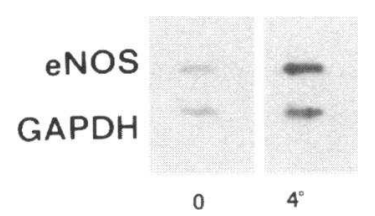

Figure 1. Northern blot demonstrating an increase in eNOS mRNA in EC exposed to either $10(A)$ or $6 \%(B)$ average strain at 60 cycles/ $\mathrm{min}$. GAPDH is the constitutive control for loading. See text for details. (C) Nuclear runoff study demonstrating that eNOS transcript levels increased significantly in response to cyclic strain, whereas GAPDH transcript levels were unaffected. Each experiment was performed at least three separate times.

for at least $4 \mathrm{~h}$ (a 1.9 \pm 0.4 -fold increase assessed by densitometry, $n=3$ ).

In an effort to get more insight into the mechanism underlying eNOS induction by cyclic strain, we performed runoff transcription assays. As shown in Fig. $1 C$, there was significant induction of new eNOS transcripts in nuclei isolated from EC exposed to $4 \mathrm{~h}$ of $10 \%$ average strain compared with nuclei from control stationary cells. The increase $(2.6 \pm 0.4, n=3)$ in eNOS transcription was specific because only minimal induction $(1.1 \pm 0.2, n=3)$ of GAPDH transcripts was observed with cyclic strain.

To directly compare the effects of low versus high strain on eNOS gene expression, the same bovine aortic EC cells were exposed to either 6 or $10 \%$ average strain at $60 \mathrm{cycles} / \mathrm{min}$ for $24 \mathrm{~h}$ followed by Northern blot analysis. Fig. $2 A$ shows that both strain regimens increased eNOS gene expression but the increase with $6 \%$ average strain was lower than that seen in EC exposed to $10 \%$ average strain. Densitometric analysis of eNOS gene expression (normalized to GAPDH) demonstrated a $1.95 \pm 0.45$-fold $(n=3)$ and $2.2 \pm 0.35$-fold $(n=3)$ increase in eNOS expression compared with static controls, respectively. Fig. $2 B$ shows that when EC were selectively seeded in the high strain periphery $(>7 \%)$ versus the low strain central region and subjected to a $-20 \mathrm{kPa}$ vacuum for $24 \mathrm{~h}$, a greater increase in eNOS transcripts was observed in cells seeded in the periphery
A

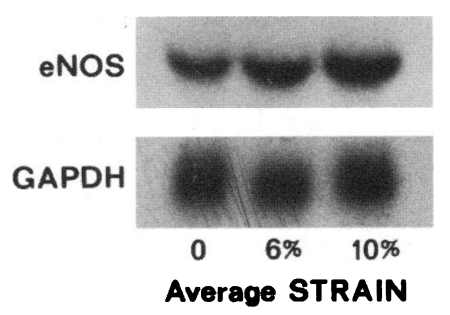

B

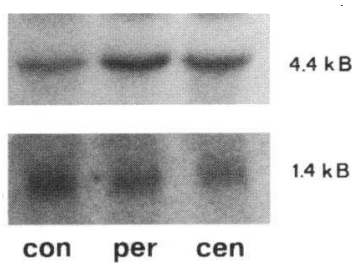

Average STRAIN

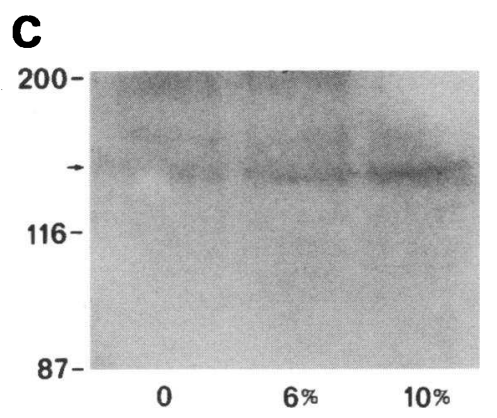

Average STRAIN

Figure 2. (A) Northern blot of EC exposed to either 6 or $10 \%$ average strain at $60 \mathrm{cycles} / \mathrm{min}$ for $24 \mathrm{~h}$. There was an increase in eNOS mRNA in both groups, although the increase in EC exposed to $6 \%$ strain was lower. $(B)$ Northern blot of EC selectively grown on the periphery or center of membranes that were deformed with $-20 \mathrm{kPa}$ vacuum at 60 cycles/min for $24 \mathrm{~h}$. There was an increase in eNOS mRNA in both groups compared with control, stationary cells. However, there was a greater increase in cells grown on the periphery (7-24\% strain) compared with the center ( $0-7 \%$ strain). $(C)$ Western blot analysis of EC exposed to either 6 or $10 \%$ average strain at 60 cycles/min for $24 \mathrm{~h}$. There was again an increase in eNOS protein in both groups. However, EC subjected to greater strain had a higher level of eNOS protein. Each experiment was performed at least three separate times.

(eNOS/GAPDH $=3.55$ ) when compared with the low strain central region $(\mathrm{eNOS} / \mathrm{GAPDH}=2.93)$.

To ascertain the significance of increased eNOS gene expression, eNOS protein levels were examined by Western blot analysis in bovine aortic EC that were subjected to 6 or $10 \%$ average strain for $24 \mathrm{~h}$. With both strain regimens there was an increase in eNOS protein after $24 \mathrm{~h}$ compared with stationary controls. Moreover, EC subjected to greater strain had a higher level (2.3-fold) of eNOS protein (Fig. $2 C$ ).

In this model of cyclic strain, the strain pattern across the stretch membrane is inhomogeneous. Typically, cells seeded in the periphery of the membrane experience maximum strain ( $24 \%$ at $20 \mathrm{kPa}$ of vacuum deformation) while cells at the very center of the membrane experience minimum strain $(0 \%)$. To examine if differential patterns of eNOS protein expression occurred in areas of high versus low strain, eNOS was localized by immunohistochemical staining. Fig. $3 a$ shows that bovine aortic EC at the periphery of the membrane (7-24\% strain) showed more intense staining compared with bovine aortic EC at the center of the membrane $(0-7 \%$ strain $)$. High power photomicrograph reveals an intense perinuclear distribution of the punctate eNOS staining and a lesser stain which appears to be arranged around intracellular vacuoles. Specificity of the staining was confirmed by the lack of staining with exposure 

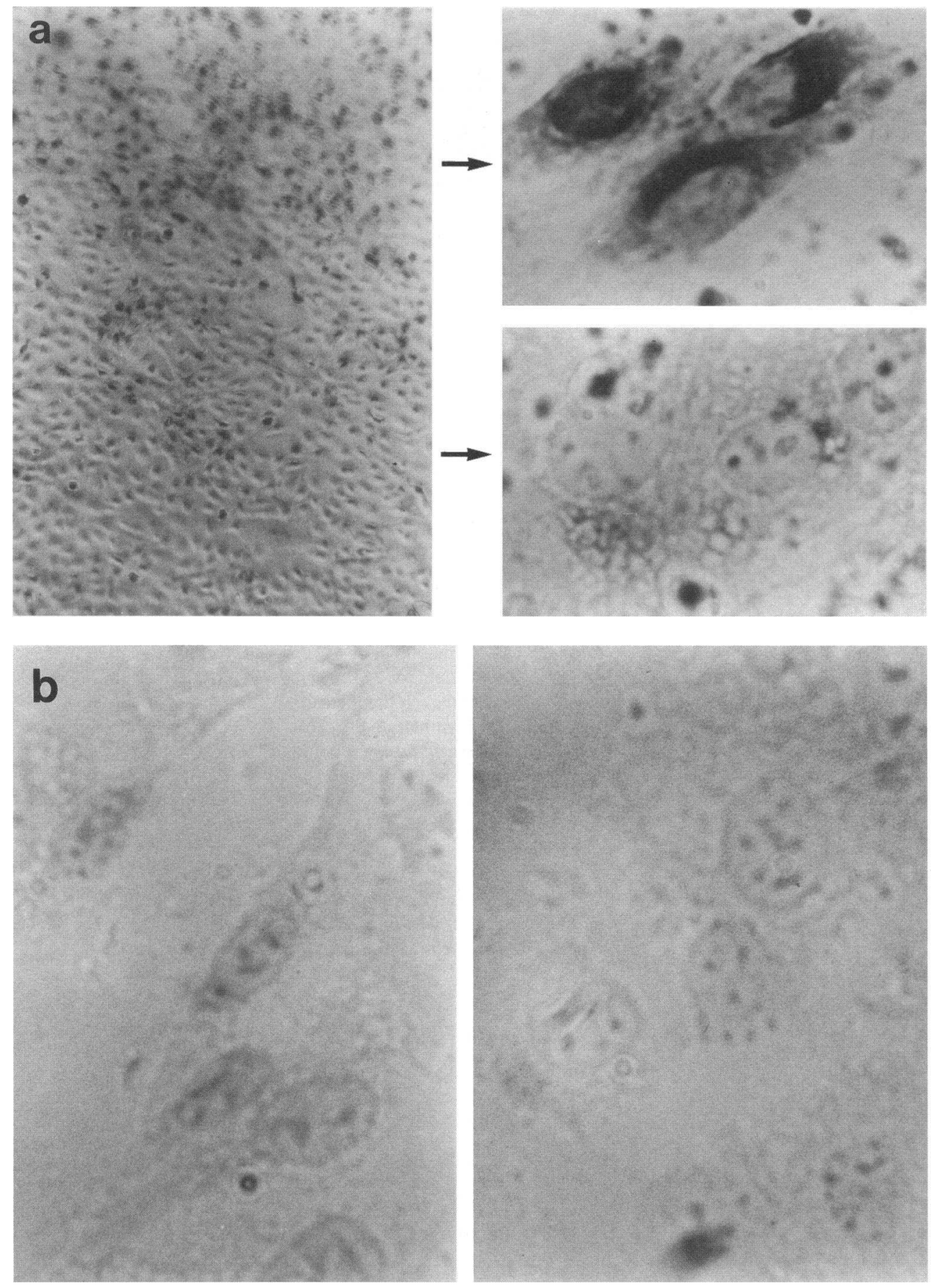

Figure 3. (a) Immunocytochemical staining with eNOS antibody of EC grown on membranes subjected to $-20 \mathrm{kPa}$ vacuum deformation at 60 cycles/min for $24 \mathrm{~h}$ (see Methods for details). The figure on the left demonstrates the differential staining pattern across the membrane, with EC at the periphery (top) showing a more robust staining compared with EC at the center of the membrane (bottom). The figures on the left are high power magnification $(\times 400)$ of individual cells in the different regions demonstrating the punctate staining. ( $b$ ) Minimal staining with eNOS antibody in control (unstretched) bovine aortic EC (left) and in EC on the periphery of stretched membranes when nonspecific mouse $\mathrm{IgG}_{2 \mathrm{a}}$ was used (right). $\times 200$.

of the bovine aortic EC to nonspecific mouse $\operatorname{IgG}_{\mathrm{a}}$ and to the biotinylated secondary antibody (horse anti-mouse) (Fig. 3 $b$, right). Unstretched bovine aortic EC showed very minimal staining (Fig. $3 b$, left).

\section{Discussion}

Studies of cultured EC exposed to mechanical forces (either cyclic strain or shear stress) have shown that EC function can be influenced by such forces. In vivo measurements in patients and animals and in vitro models replicating the major geometric features of blood vessels indicate that there is $5-6 \%$ wall excur- sion at peak systole under normal physiologic conditions, which can increase to $10 \%$ during hypertensive states (29-31). Previously, we have demonstrated that cyclic strain alters various parameters of EC function such as the production of vasoactive substances (21-23). In addition, cyclic strain also increases EC proliferation and changes EC morphology (orientation of the long axis of the cell perpendicular to the axis of the strain) $(24,32)$. Likewise, several authors have demonstrated that shear stress will also alter production of vasoactive substances $(15,33,34)$. Thus both cyclic strain and shear stress appear to regulate EC function.

Our present studies demonstrate that cyclic strain (at two 
different strain regimens) increases eNOS gene expression in bovine aortic EC. Direct comparison of the two strain regimens showed that there was a differential expression of eNOS gene with $10 \%$ average strain, inducing a more rapid and robust increase in eNOS gene transcription compared with $6 \%$ average strain. Although Nishida and colleagues (15) have demonstrated an increase in steady state eNOS mRNA in EC exposed to $10 \mathrm{dyn} / \mathrm{cm}^{2}$ shear stress, this paper is the first report of upregulation of eNOS transcription by a mechanical force (Fig. $1 C$ ). In addition, the enhanced mRNA levels are associated with increased protein levels assessed by Western blotting. There was a differential increase in eNOS protein levels similar to that seen in the Northern blot experiments with the protein levels greater in EC exposed to $10 \%$ average strain compared with $6 \%$ average strain. The differential effect of strain was also supported by increased eNOS mRNA levels and greater eNOS-specific staining in the high strain membrane periphery (7-24\% strain) in comparison to the low strain center. These results comprise the first demonstration that cyclic strain regulates the expression of eNOS. The functional effect of this increased eNOS expression is confirmed by our recent report which demonstrated a strain-dependent increase (61\%) in eNOS activity by the L-citrulline assay and a 4.75 -fold increase in nitrite accumulation (Greiss assay) in bovine aortic EC exposed to $24 \mathrm{~h}$ of cyclic strain (35). These data corroborate the previous report that shear stress increases eNOS gene and protein, and both studies are consistent with recent in vivo studies showing that hemodynamic forces can alter endothelium-dependent relaxations and eNOS. Taken together, our studies and the findings of others suggest that eNOS and ultimately NO production can be regulated by changes in pulsatile flow.

The differential expression of eNOS in EC exposed to strain is similar to previous studies which have demonstrated EC proliferation (24), tissue plasminogen activator expression (20), and adenylate cyclase/protein kinase A activation (36) in response to different strain levels. In addition to the effect of $10 \%$ average strain on the level of eNOS gene and protein, this strain regimen also appeared to induce a more rapid increase in eNOS gene expression. Increased expression of eNOS gene started after 15 min of exposure to $10 \%$ average strain compared with $2 \mathrm{~h}$ with $6 \%$ average strain. The rapid increase in eNOS mRNA level in EC exposed to $10 \%$ average strain suggests that other mechanisms (apart from transcriptional activation) may be involved. Measurements of eNOS transcription rate and mRNA half-life to assess strain-induced posttranscriptional modifications will be needed to specifically address these issues.

Likewise, the mechanism for the regulation of eNOS by cyclic strain is still unknown. eNOS expression may be potentially regulated at several points in the protein synthesis pathway. eNOS mRNA levels may be changed by alterations in mRNA transcription or by posttranscriptional modifications which change the rate of mRNA degradation, and finally eNOS protein levels may be controlled by changes in protein stability. Previous studies in our laboratory have demonstrated that cyclic strain alters the second messenger metabolic pathways which may potentially play a role in the regulation of eNOS. For example, cyclic strain leads to activation of protein kinase A/ adenylate cyclase (36), thereby increasing intracellular cAMP which is also accompanied by an increased binding of the nuclear factor, cAMP responsive element (CRE) binding protein. Other investigators have shown that increased intracellular cAMP levels may play a role in the regulation of NO production
(37). Interestingly, the promoter region of the human eNOS gene has a CRE binding site $(10,38)$ and while there is no direct evidence to implicate CRE in the regulation of eNOS in bovine $\mathrm{EC}$, we can postulate that CRE may play a role in the regulation of this gene. Furthermore, we have shown recently that strain activates nuclear factors which bind to AP-1 (39) and the shear stress responsive element $(40,41)$. Shear stress responsive element and AP-1 binding sites have also been demonstrated in the human eNOS promoter $(10,38)$, therefore, cyclic strain-induced binding of these nuclear factors to the eNOS promoter may mediate amplification of the mRNA in EC exposed to strain.

The importance of strain-induced increases in eNOS is not yet known but we postulate that it may contribute to the effect of sustained dynamic exercise on cardiovascular disease. Recent studies have shown that dynamic exercise reduces the incidence of cardiovascular events $(42,43)$ and hypertension in patients (44). In addition, exercise also lowers resting blood pressure in hypertensive (45) and normotensive (46) adults and improves exercise tolerance in patients with ischemic heart disease (47) and peripheral vascular disease (48). Although exercise is currently prescribed as a therapy in the management and prevention of cardiovascular disease, the mechanisms underlying the benefits of exercise are not known. Several in vivo studies have shown that increases in hemodynamic forces can alter endothelium blood vessel tone and reactivity. Creation of arteriovenous anastomosis, which results in an increase in regional blood flow, enhances endothelium-dependent relaxations (13) and exercise training has been shown to increase endothelial-dependent vasodilator response in rat aorta (49). Furthermore, exercise produces an NO-dependent attenuation of the response of rats to phenylephrine (50), suggesting that exercise may buffer the hypertensive response to adrenergic stimulation through NO production. More recently, we have demonstrated that chronic exercise in dogs increases the release of nitrogen oxides from large coronary arteries and microvessels and specifically increases eNOS expression in aortic EC extracts (14). Human studies also show that sustained exercise leads to increased urinary nitrate excretion which indicates an increased NO production (51). While these in vivo studies demonstrate the effect of hemodynamics on production of NO, it is difficult to analyze the contribution of the different hemodynamic forces. The present study suggests that the rhythmic distention of the arterial wall which is a component of pulsatile flow may play an important role in the regulation of eNOS in vivo.

In summary, cyclic strain increases eNOS gene expression, protein, and activity (35) in cultured bovine aortic EC. The mechanisms responsible for these effects are presently not known. However, these results indicate the importance of hemodynamic forces in the regulation of eNOS in vivo.

\section{Acknowledgments}

We would like to thank Dr. Jennifer S. Pollock for her generous supply of the eNOS monoclonal antibody.

This work was supported in part by grants to B. E. Sumpio (National Institutes of Health grants R29 HL-40305 and R01 HL-47345, and a grant from the Veterans Administration Merit Board). M. A. Awolesi is supported by National Institutes of Health NRSA HL-08675. W. C. Sessa is supported, in part, by grants from the Pharmaceutical Manufacturers Association and the Patrick and Catherine Weldon Donaghue Medical Research Foundation. The Molecular Cardiobiology Program at Yale is supported by American Cyanamid. 


\section{References}

1. Radomski, M. W., R. M. Palmer, and S. Moncada. 1987. Comparative pharmacology of endothelium-derived relaxing factor, nitric oxide and prostacyclin in platelets. Br. J. Pharmacol. 921:181-187.

2. Kubes, P., M. Suzuki, and D. N. Granger. 1991. Nitric oxide: an endogenous modulator of leukocyte adhesion. Proc. Natl. Acad. Sci. USA. 8811:4651-4655.

3. Palmer, R. M., and S. Moncada. 1989. A novel citrulline-forming enzyme implicated in the formation of nitric oxide by vascular endothelial cells. Biochem. Biophys. Res. Commun. 1581:348-352.

4. Palmer, R. M., D. D. Rees, D. S. Ashton, and S. Moncada. 1988. L-arginine is the physiological precursor for the formation of nitric oxide in endotheliumdependent relaxation. Biochem. Biophys. Res. Commun. 1533:1251-1256.

5. Schmidt, H. H. H., H. Nau, W. Wittfoht, J. Gerlach, K. E. Prescher, M. M. Klein, F. Niroomand, and E. Bohme. 1988. Arginine is a physiological precurso of endothelium derived nitric oxide. Eur. J. Pharmacol. 154:213-216.

6. Pollock, J. S., M. Nakane, L. D. Buttery, A. Martinez, D. Springall, J. M. Polak, U. Forstermann, and F. Murad. 1993. Characterization and localization of endothelial nitric oxide using specific monoclonal antibodies. Am. J. Physiol. 265:C1379-C1387.

7. Leone, A. M., R. M. Palmer, R. G. Knowles, P. L. Francis, D. S. Ashton, and S. Moncada. 1991. Constitutive and inducible nitric oxide synthases incorporate molecular oxygen into both nitric oxide and citrulline. J. Biol. Chem. 26635:23790-23795.

8. Sessa, W. C., J. K. Harrison, C. M. Barber, D. Zeng, M. E. Durieux, D. D D'Angelo, K. R. Lynch, and M. J. Peach. 1992. Molecular cloning and expression of a cDNA encoding endothelial cell nitric oxide synthase. J. Biol. Chem. 26722:15274-15276.

9. Marsden, P. A., K. T. Schappert, H. S. Chen, M. Flowers, C. L. Sundell, J. Wilcox, S. Lamas, and T. Michel. 1992. Molecular cloning and characterization of human endothelial nitric oxide synthase. FEBS Lett. 3073:287-293.

10. Marsden, P. A., H. H. Q. Heng, S. W. Scherer, R. J. Stewart, A. V. Hall, X. Shi, L. Tsui, and K. T. Schappert. 1993. Structure and chromosomal localization of the human constitutive endothelial nitric oxide synthase gene. J. Biol. Chem. 26823:17478-17488.

11. Ando, J., A. Ohtsuka, R. Korenaga, I. Sakuma, and A. Kamiya. 1993 Flow-induced calcium transients and release of endothelium-derived relaxing factor in cultured vascular endothelial cells. Front. Med. Biol. Eng. 51:17-21.

12. Loeb, A. L., N. J. Izzo, R. M. Johnson, J. C. Garrison, and M. J. Peach 1988. Endothelium-derived relaxing factor release associated with increased endothelial cell inositol trisphosphate and intracellular calcium. Am. J. Cardiol. 65:6211-6215.

13. Miller, V. M., and J. J. Burnett. 1992. Modulation of NO and endothelin by chronic increases in blood flow in canine femoral arteries. Am. J. Physiol. 248:H432-H437.

14. Sessa, W., K. Pritchard, N. Seyedi, J. Wang, and T. Hintze. 1994. Chronic exercise in dogs increases coronary vas cular nitric oxide production and endothelial cell nitric oxide synthase gene expression. Circ. Res. 74:349-353.

15. Nishida, K., D. G. Harrison, J. P. Navas, A. A. Fisher, S. P. Dockery, M. Uematsu, R. M. Nerem, R. W. Alexander, and T. J. Murphy. 1992. Molecular cloning and characterization of the constitutive bovine endothelial cell nitric oxide synthase. J. Clin. Invest. 90:2092-2093.

16. Rosales, O. R., and B. E. Sumpio. 1992. Changes in cyclic strain increase inositol trisphosphate and diacylglycerol in endothelial cells. Am. J. Physiol. 262:C956-C962.

17. Rosales, O. R., and B. E. Sumpio. 1992. Protein kinase C is a mediator of the adaptation of vascular endothelial cells to cyclic strain in vitro. Surgery (St. Louis). 112:452-466.

18. Letsou, G. V., O. Rosales, S. Maitz, A. Vogt, and B. E. Sumpio. 1990 Stimulation of adenylate cyclase activity in cultured endothelial cells subjected to cyclic stretch. J. Cardiovasc. Surg. 315:634-639.

19. Sumpio, B. E., W. Du, C. R. Cohen, L. Evans, C. Isales, O. R. Rosales, and I. Mills. 1994. Signal transduction pathways in vascular cells exposed to cyclic strain. Soc. Exp. Biol. Semin. Ser. (Biomechanics and Cells). 54:3-22.

20. Iba, T., and B. E. Sumpio. 1992. Tissue plasminogen activator expression in endothelial cells exposed to cyclic strain in vitro. Cell Transplant. 1:43-50.

21. Sumpio, B. E., and A. J. Banes. 1988. Prostacyclin synthetic activity in cultured aortic endothelial cells undergoing cyclic mechanical deformation. Sur gery (St. Louis). 104:383-389.

22. Sumpio, B. E., and M. D. Widmann. 1990. Enhanced production of endothelium-derived contracting factor by endothelial cells subjected to pulsatile stretch. Surgery (St. Louis). 1082:277-281.

23. Sumpio, B. E., editor. 1993. Hemodynamic Forces and Vascular Cell Biology. R. G. Landes Co., Austin, TX. 1-119.

24. Li, G., I. Mills, and B. E. Sumpio. 1994. Cyclic strain stimulates endothelial cell proliferation: characterization of strain requirements. Endothelium. 2:177181.

25. Banes, A. J., J. Gilbert, D. Taylor, and O. Monbureau. 1985. A new vacuum-operated stress-providing instrument that applies static or variable duration cyclic tension or compression to cells in vitro. J. Cell Sci. 7535:35-42.

26. Gilbert, J. A., A. J. Banes, G. W. Link, and G. L. Jones. 1990. Video analysis of membrane strain: an application in cell stretching. Experimental Techniques. 14:43-45.

27. Chirgwin, J. M., R. J. Pryzblya, I. Macdonald, and W. J. Rutter. 1978. Isolation of biologically active ribonucleic acid from sources enriched in ribonuclease. Biochemistry. 8:5294-5299.

28. Greenberg, M. E., and E. B. Ziff. 1984. Stimulation of 3 T3 cells induces transcription of the c-fos proto-oncogene. Nature (Lond.). 311:433-438.

29. Patel, D. J., J. C. Greenfield, W. G. Austen, A. G. Morrow, and D. L. Fry 1965. Pressure-flow relationships in the ascending aorta and femoral artery of man. J. Appl. Physiol. 20:459-463.

30. Bergel, D. H. 1961. The static elastic properties of the arterial wall. $J$. Physiol. 156:445-457.

31. Steinman, D. A., and C. R. Ethier. 1994. The effect of wall distensibility on flow in a 2D end-to-side anastomosis. J. Biomech. Eng. 116:294-301.

32. Iba, T., and B. E. Sumpio. 1991. Morphological response of human endothelial cells subjected to cyclic strain in vitro. Microvasc. Res. 423:245-254.

33. Frangos, J. A., S. G. Eskin, L. V. McIntire, and C. L. Ives. 1985. Flow effects on prostacyclin production by cultured human endothelial cells. Science (Wash. DC). 227:1477-1479.

34. Diamond, S. L., S. G. Eskin, and L. V. McIntire. 1989. Fluid flow stimulates tissue plasminogen activator secretion by cultured human endothelial cells. Science (Wash. DC). 243:1483-1485.

35. Awolesi, M. A., M. D. Widmann, W. C. Sessa, and B. E. Sumpio. 1994 Cyclic strain increases endothelial nitric oxide synthase activity. Surgery (St Louis). 116:439-445.

36. Cohen, C. R. G., I. Mills, and B. E. Sumpio. 1993. The activity of cyclic AMP dependent protein kinase (PKA) is increased by acute cyclic strain in endothelial cells (EC) in vitro. FASEB (Fed. Am. Soc. Exp. Biol.). 7:A786.

37. Graier, W. F., K. Groschner, K. Schmidt, and W. R. Kukovetz. 1992. Increases in endothelial cyclic AMP levels amplify agonist-induced formation of endothelium-derived relaxing factor (EDRF). Biochem. J. 288:345-349.

38. Robinson, L. J., S. Weremowicz, C. C. Morton, and T. Michel. 1994. Isolation and chromosomal localization of the human endothelial nitric oxide synthase gene. Genomics. 19: 350-357.

39. Sumpio, B. E., W. Du, and W. Xu. 1994. Exposure of endothelial cells to cyclic strain induces c-fos, fosB and c-jun but not junB or junD and increases the transcription factor AP-1. Endothelium. 2:149-156.

40. Resnick, N., T. Collins, W. Atkinson, D. T. Bonthron, C. F. Dewey, and M. A. Gimbrone. 1993. Platelet-derived growth factor B-chain promoter contains a cis-acting fluid shear stress-responsive element. Proc. Natl. Acad. Sci. USA. 90:4591-4595.

41. Resnick, N., B. E. Sumpio, W. Du, and M. A. Gimbrone. 1995. Endothelial regulation by biomechanical forces. Proceedings, 10th International Symposium on Atherosclerosis. In press.

42. Hellenius, M. L., B. Berglund, A. Hamsten, and I. Krakau. 1993. Diet and exercise are equally effective in reducing risk for cardiovascular disease. Results of a randomized controlled study in men with slightly to moderately raised cardiovascular risk factors. Atherosclerosis. 1031:31-91.

43. Posner, J. D., K. M. Gorman, L. N. Gitlin, L. P. Sands, M. Kleban, L. Windsor, and C. Shaw. 1990. Effects of exercise training in the elderly on the occurrence and time to onset of cardiovascular diagnoses. J. Am. Geriatr. Soc. 383:205-210.

44. Paffenbarger, R. S., A. L. Wing, R. T. Hyde, and D. L. Jung. 1983. Physical activity and incidence of hypertension in college alumni. Am. J. Epidemiol. 117:245-257.

45. Nakamura, M., H. Itoh, C. Ikeda, E. Yanigasawa, Y. Miyazawa, F. Hatogai, and M. Iwadare. 1992. The efficacy of aerobic exercise therapy on hypertensive patients with mild cardiac complications. Ann. Acad. Med. 211:38-41.

46. Poehlman, E. T., A. W. Gardner, P. A. Ades, S. M. Montgomery, O. K. Atlas, D. L. Ballor, and R. S. Tyzbir. 1992. Resting energy metabolism and cardiovascular disease risk in resistance-trained and aerobically trained males. Metab. Clin. Exp. 41:1351-1360.

47. Ehsani, A. A., G. W. Heath, J. M. Hagberg, B. E. Sobel, and J. O. Holloszy. 1981. Effects of 12 months of intense exercise training on ischemic segment depression in patients with coronary disease. Circulation. 64:1116-1124.

48. Hiatt, W. R., J. G. Regensteiner, M. E. Hargerten, E. E. Wolfel, and E. P. Brass. 1990. Benefits of exercise conditions for patients with peripheral arterial disease. Circulation. 81:602-609.

49. Delp, M. D., R. M. McAllister, and M. H. Laughlin. 1993. Exercise training alters endothelium-dependent vasoreactivity of rat abdominal aorta. $J$. Appl. Physiol. 753:1354-1363.

50. Patil, R. D., S. E. DiCarlo, and H. L. Collins. 1993. Acute exercise enhances nitric oxide modulation of vascular response to phenylephrine. Am. J. Physiol. 265:1184-1188.

51. Leaf, C. D., J. S. Wishnok, J. P. Hurley, W. D. Rosenblad, J. G. Fox, and S. R. Tannenbaum. 1990. Nitrate biosynthesis in rats, ferrets and humans. Precursor studies with L-arginine. Carcinogenesis. 115:855-858. 